\title{
EVALUASI KOMPOSISI BOTANI DAN NILAI NUTRIEN PADA RUMPUT DI RAWA KECAMATAN MENGGALA KABUPATEN TULANG BAWANG
}

\author{
Evaluation of Botanical Composition and Nutrient of Grass in Swamp of Menggala Sub-District \\ Tulang Bawang Regency
}

Ridho Akbar, Liman, dan Agung Kusuma Wijaya

Department of Animal Husbandry, Faculty of Agriculture, Lampung University

Soemantri Brojonegoro No.1 Gedong Meneng, Rajabasa, Bandar Lampung, Lampung Province e-mail: tnridho@gmail.com

\begin{abstract}
This research aimed to determine the botanical composition and nutrient value of grass in swamp of Menggala Sub-District Tulang Bawang Regency Lampung Province in August--October 2017. This research used survey method with purposive sampling. The data obtained from this study consisted of primary and secondary datas. The result showed that the botanical composition contained in the swamp of Hymenachne amplexicaulis 59,93\%; Cynodon dactylon L. Pars 18,54\%; Fimbristylis vahlii 7,54\%; Brachiaria plantaginea 7,39\% and Isachne indica Nees 6,60\%. The average nutrient of grass contained in swamp of Menggala Sub-District were dry material 19.72\%; crude fiber 28,90\%; crude protein $5.72 \%$; crude fat $4.51 \%$; ash $14.05 \%$; and NFE $42.16 \%$.
\end{abstract}

Keywords: Botanical Composition, Menggala Sub-District, Nutrient Value, Swamp

\section{PENDAHULUAN}

Kecamatan Menggala Kabupaten Tulang Bawang Provinsi Lampung adalah daerah ternak kerbau dengan pemeliharaan kerbau masih menggunakan metode konvensional yaitu belum adanya teknologi, pemeliharaan hanya dengan cara pengembalaan di rawa ataupun sungai. Badan Pusat Statistik Kabupaten Tulang Bawang (2016) menyatakan bahwa pada tahun 2015 populasi kerbau sebesar 4.006 ekor.

Kabupaten Tulang Bawang memiliki luasan lahan rawa berdasarkan hasil pemetaan Direktur Jenderal Tanaman Pangan tahun 2015 seluas 1500 Ha. Padang penggembalaan merupakan suatu area yang ditumbuhi vegetasi dominan famili Gramineae dan mungkin juga terdapat jenis tumbuhan lainya seperti legume, dan herba lainya yang digunakan untuk makanan ternak. Padang penggembalaan daerah tropis biasanya menghasilkan hijauan yang melimpah pada musim hujan, setelah itu tunas tanaman biji tumbuh dan berkembang dengan baik dan cepat.

Kualitas padang pegembalaan umumnya rendah, karena kerusakan vegetasi akibat berkembangnya tanaman pengganggu (gulma) yang mendominasi padang penggembalaan sehingga menekan tanaman inti yang disukai ternak. Padang penggembalaan potensial yang terintervensi oleh gulma dapat menjadi tanah kritis serta kurang responsif terhadap perbaikan unsur hara tanah (Bambang dan Priyanto, 2017). Rendahnya nilai nutrien padang gembala disebabkan juga oleh proporsi legume yang rendah karena padang gembala bersifat tidak dinamis, seperti komposisi vegetasi yang dapat berubah-ubah karena faktor iklim, tanah, grazing, dan manusia.

Upaya yang dilakukan dalam pembangunan di sektor pertanian salah satunya yaitu dengan meningkatkan kawasan lahan hijauan tanaman pakan dengan pengembangan kawasan tanaman hijauan pakan di rawa. Fariani dan Evitayani (2008) menyatakan bahwa rawa terdiri atas dua jenis, yaitu rawa pasang surut dan rawa lebak. Meningkatnya lahan hijauan tanaman pakan akan berimplikasi pada meningkatnya produksi tanaman hijauan untuk memenuhi kebutuhan produksi ternak, karena pakan hijauan berfungsi sebagai bulk dan juga sebagai sumber karbohidrat, protein, vitamin, dan mineral. Pertambahan populasi yang begitu pesat akan menyebabkan peningkatan kebutuhan suplai pakan hijauan, hal ini akan mengakibatkan lebih banyak sumber daya lahan yang diperlukan untuk dijadikan sebagai tempat penggembalaan ternak.

Penelitian ini dilakukan untuk mengetahui komposisi botani dan nilai nutrien pada rumput 
Rawa di Kecamatan Menggala Kabupaten Tulang Bawang Provinsi Lampung

\section{MATERI DAN METODE}

Penelitian ini dilaksanakan pada Agustus--Oktober 2017. Materi penelitian terdiri atas lahan hijauan, jenis-jenis hijauan maupun legum yang berada di rawa pada Kecamatan Menggala, Kabupaten Tulang Bawang, Provinsi Lampung. Alat-alat yang digunakan dalam penelitian ini adalah pisau sabit, karung, kantung plastik, timbangan duduk/timbangan analitik, tali plastik, gunting, patok kayu, scroll meter, alat tulis, alat hitung, dan kamera.

Penelitian ini menggunakan metode survei purposive sampling. Purposive sampling dilakukan dengan menentukan kriteria sebagai berikut : (a) kondisi rawa yang tidak tergenang air, (b) luasan rawa yang diketahui luasnya, (c) rawa yang digunakan untuk lahan penggembalaan, dan (d) kondisi lingkungan rawa yang dapat diambil sampel oleh peneliti. Cuplikan ditentukan secara acak, ubinan dilakukan seluas 1 meter persegi, petak kedua diambil pada jarak 10 langkah lurus ke kanan, kedua petak ini merupakan 1 cluster. Cluster kedua diambil sejauh 125 meter dari cluster sebelumnya.

\section{HASIL DAN PEMBAHASAN}

\section{Komposisi Botani Rawa}

Penelitian yang dilakukan pada rawa Kecamatan Menggala, Kabupaten Tulang Bawang, diperoleh terdapat 5 spesies vegetasi rawa yang diklasifikasikan sebagai rumput dominan yang tumbuh. Jenis-jenis vegetasi alam yang ditemukan di rawa Kecamatan Menggala Kabupaten Tulang Bawang disajikan pada Tabel 1.

Tabel 1. Persentase Vegetasi Rawa di Kecamatan Menggala, Kabupaten Tulang Bawang

\begin{tabular}{clr}
\hline No & \multicolumn{1}{c}{ Vegetasi Rawa } & Rank $(\%)$ \\
\hline \hline 1 & Hymenachne amplexicaulis & 59,93 \\
2 & Fimbristylis vahlii & 7,54 \\
3 & Isachne indica Nees & 6,60 \\
4 & Cynodon dactylon L. Pars & 18,54 \\
5 & Brachiaria plantaginea & 7,39 \\
\hline \multicolumn{2}{c}{ Total } & 100,00 \\
\hline
\end{tabular}

Keterangan: hasil penelitian

Ragamnya komposisi botani vegetasi yang tumbuh pada rawa menunjukkan perbedaan yang spesifik. Keanekaragaman vegetasi yang tumbuh pada rawa ini sangat dipengaruhi oleh musim dimana ada beberapa jenis tumbuhan yang tidak tumbuh dimusim saat rawa surut atau pasang, maka spesies lain akan berusaha tumbuh menggantikannya untuk mempertahankan kestabilan komunitas. Penelitian ini dilaksanakan pada waktu rawa surut. Menurut BPS Kabupaten Tulang Bawang (2016), curah hujan pada bulan Agustus-Oktober sekitar 8,0--11,0 $\mathrm{mm}^{3}$.

Hal ini sesuai dengan pendapat Bucio et al. (2005) mengemukakan bahwa kestabilan komunitas tanaman dipengaruhi oleh lingkungan biotik (ternak) dan abiotik (air, tanah dan iklim), sehingga tanaman yang tidak bisa tumbuh pada keadaan tersebut maka spesies lain menggantikan. Rohaeni et al. (2007) melaporkan bahwa kestabilan pertumbuhan tanaman dipengaruhi faktor-faktor lingkungan, terutama fluktuasi level air berpengaruh terhadap ekosistem rawa. Faturrahman (1988) menyatakan keragaman spesies tanaman rawa tidak terkonsentrasi pada satu dua jenis spesies saja, tetapi tanaman yang tahan akan membagi diri untuk menutupi area secara optimum dan menjaga kestabilan komunitas.

\section{Hymenachne amplexicaulis (Kumpai Minyak) \\ Rawa Kecamatan Menggala memiliki} spesies rumput dominan yaitu Hymenachne amplexicaulis. Rumput ini merupakan rumput yang dapat hidup di rawa. Rumput ini bertipe bunga majemuk berupa malai tegak dengan panjang 15--25 cm dan mempunyai bulir sekitar 20 buah. Menurut Backer dan Brenk (1968) dan Heyne (1987), panjang bunga dapat mencapai 10--40 cm, sangat tipis dan lebat, sering berupa bulir, yang hanya bercabang dibagian bawah, berwarna hijau muda, bergagang pendek serta lancip dengan panjang 3--5 mm. Rumput kumpai tumbuh pada daerah dengan ketinggian mencapai 100 mdpl. Berdasarkan data BPS Kabupaten Tulang Bawang (2015) menyatakan bahwa ketinggian wilayah Menggala sekitar 37 mdpl. Rumput ini sangat dominan tumbuh di rawa Kecamatan Menggala.

\section{Fimbristylis vahlii (Teki Rawa)}

Fimbristylis vahlii merupakan vegetasi yang dapat hidup di rawa. Fimbristylis (bahasa Inggris: fimbry, fimbristyle, fringe-rush) adalah genus dari teki-tekian. Teki-tekian ini memiliki batang yang kaku dan berbubungan serta panicle terminal berbentuk kerucut dari spikelet. Rumput ini dapat hidup di lingkungan basah, ditemukan di daerah beriklim sedang 
dan tropis yang di seluruh dunia. Gupta dan Thacker (2013) menyatakan, Fimbristylis vahlii berasal dari Asia dan kemungkinan dinaturalisasi di Amerika.

Fimbristylis vahlii dapat tumbuh di rawa Kecamatan Menggala dengan sangat baik, karena BPS Kabupaten Tulang Bawang (2015) menyatakan bahwa ketinggian wilayah Menggala yaitu 37 mdpl. Hal ini sesuai dengan pendapat Gupta dan Thacker (2013) menyatakan, rumput ini dapat hidup di ketinggian 0--4000 mdpl, biasanya tumbuh di padang rumput lembab, air dangkal di rawarawa, di sepanjang sungai dan kanal irigasi, dan juga sebagai gulma di sawah. Rumput ini bisa ditanam untuk stabilisasi lereng dan dipanen sebagai pakan hewan (ternak). Tidak diperlukan tindakan konservasi, spesies ini hidup di sejumlah kawasan lindung di berbagai wilayah.

\section{Isachne indica Nees (Banta)}

Isachne indica Nees adalah rumput yang tumbuh dirawa, rumput ini memiliki batang yang berongga, daunnya terasa gugup, dan perbungaan bisa menjadi malai terbuka atau sempit. Menurut Lansdown (2013), memiliki bentuk yang khas, yaitu memiliki spikelet dengan floret hanya sedikit berbeda, hampir sama panjang dan teksturnya dan floret bagian atas membulat di bagian belakang tanpa alur sentral. Spikelet berbentuk bulat seperti bola.

Menurut Lansdown (2013), genus tanaman tropis dan subtropis yang tersebar luas di keluarga rumput, ditemukan di Asia, Afrika, Australia, Amerika, dan berbagai pulau samudra. Isachne indica Nees dikenal secara umum sebagai bloodgrasses atau rumput abadi.

\section{Cynodon dactylon L. Pars (Suntilang)}

Cynodon dactylon L. Pars adalah adalah gulma umum invasif yang tidak diketahui adanya ancaman saat ini. Oleh karena itu spesies ini dinilai sebagai Least Concern. Jenis rumput ini memiliki kemampuan agak berlebihan dalam hal bertahan hidup, jika dibdaningkan rumput jenis lain seperti rumput teki, gajah, manila, dan sebagainya. Rumput ini mampu bertahan hidup di lahan yang tandus dalam musim kemarau sekalipun pertumbuhan daunnya menjadi minim. Ketika terkena mata bajak dan garu pun rumput ini akan tetap terus hidup selama akarnya bersinggungan dengan tanah.

Habitat Cynodon dactylon L. Pars adalah tumbuh paling bagus pada suhu di atas $24^{\circ} \mathrm{C}$. Hal ini sesuai menurut BPS Kabupaten Tulang Bawang (2016) menyatakan suhu udara pada bulan Agustus--Oktober sekitar 26,80--28,20 ${ }^{\circ} \mathrm{C}$ dengan kelembaban udara rata-rata 68--75\% maka rumput ini dapat hidup dengan baik di rawa Kecamatan Menggala. Jenis ini toleran terhadap kekeringan. Tumbuh paling baik pada tanah berdrainase baik tetapi toleran terhadap banjir yang berkepanjangan. Toleran terhadap kisaran $\mathrm{pH}$ tanah yang luas, tetapi $\mathrm{pH}$ optimal di atas 5,5. Tumbuh paling baik pada tanah memiliki drainase baik dan toleran terhadap kesuburan tanah yang rendah tetapi tidak toleran terhadap naungan. Penyebarannya selain dari akar yang dapat membuat rimpang dengan cepat juga melalui buah. Penyebaran buah ini yang dapat meluas. Spesies ini digunakan sebagai spesies pakan, karena tingkat pertumbuhannya yang tinggi dan kemampuan untuk mempertahankan pertumbuhan selama bulan-bulan musim panas yang hangat saat sebagian besar rumput hijauan lainnya turun sementara (Bethel et al., 2005).

\section{Brachiaria plantaginea (Jajagungan)}

Brachiaria adalah rumput tahunan atau abadi. Pada penelitian ini rumput Brachiaria plantaginea sedikit memiliki rimpang, dengan perbungaan adalah malai bercabang, dan tanaman mencapai $20 \mathrm{~cm}$ tingginya. Hal ini sesuai dengan Menurut Fanindi dan Prawiradiputra (2017), memiliki rhizoma yang pendek dan tinggi batang sekitar $10--50 \mathrm{~cm}$, tanamannya biseksual dan bunganya berdaging, dengan 3 anter. Spesies ini memiliki pembuluh darah yang menonjol di bagian tengah daun.

Spesies ini dapat hidup dengan subur di rawa Kecamatan Menggala yang beriklim tropis. Menurut Fanindi dan Prawiradiputra (2017), Brachiaria adalah rumput unggul yang bisa tumbuh baik di daerah tropis terutama tropis basah, dapat sebagai rumput untuk grazing atau cut dan carry, memiliki nilai nutrien yang baik dan sudah biasa diberika oleh peternak.

Brachiaria plantaginea (Jajagungan) dianggap sebagai gulma ladang tebu yang cukup umum, pinggir jalan, padang rumput terbuka dan pantai, yang dilaporkan berasal dari ketinggian antara permukaan laut dan sekitar $800 \mathrm{~m}$ di Fiji dan terkadang ditemukan di tempat sampah dan halaman rumput, lahan pertanian atau ladang rumput di Guam, pinggir jalan, kebun dan tanaman tahunan, sering menyerang padang rumput yang sangat menyeramkan dan menghalangi pembentukan kembali rerumputan yang lebih baik dari dataran rendah sampai sekitar $1.200 \mathrm{~m}$ di New Guinea dan di lereng bukit dan lahan basah, terutama di daerah budidaya dan irigasi di Jazirah Arab (Cope et al., 2007). 


\section{Kandungan Nutrien Vegetasi Rawa}

Kandungan serat kasar pada rumput rawa yaitu sebesar 28,90\%. Hal ini sesuai pendapat Rohaeni et al. (2007) menyatakan bahwa kandungan serat kasar rata-rata hanya 28,04\%. Anitawati (1981) melaporkan bahwa kecernaan kandungan serat kasar untuk ternak kambing sebesar $17,9 \%$. Kecernaan pada ternak domba yang dilaporkan Mathius et al., (1981) sebesar 30,7\%. Serat kasar merupakan kemudahan bagi makluk hidup untuk mendapatkan zat-zat yang dibutuhkan oleh tubuh. Danuarsa (2006) menyatakan bahwa kandungan serat kasar yang tinggi akan menurunkan koefisiensi cerna dalam bahan pakan tersebut, karena serat kasar megandung bagian yang sukar untuk dicerna. Hasil analisis proksimat disajikan pada Tabel 2.

Tabel 2. Rata-Rata Kandungan Nilai Nutrien Vegetasi pada Rawa Kecamatan Menggala

\begin{tabular}{ccccccc}
\hline Sampel & BK & SK & PK & LK & Abu & BETN \\
\hline \hline $\begin{array}{c}\text { Vegetasi } \\
\text { rawa }\end{array}$ & 19,72 & 28,90 & 5,72 & 4,51 & 14,05 & 42,16 \\
\hline
\end{tabular}

Keterangan:

Hasil analisis proksimat di Laboratorium Nutrisi dan Makanan Ternak Jurusan Peternakan, Fakultas Pertanian, Universitas Lampung

BK : Bahan kering

LK : Lemak kasar

SK : Serat kasar

PK : Protein Kasar

BETN : Bahan ektrak tanpa nitrogen

Protein kasar vegetasi rawa Kecamatan Menggala yaitu sebesar 5,72\%. Persentase protein kasar pada vegetasi rawa Kecamatan Menggala yaitu kualitas sedang. Hal ini sesuai yang dikemukakan oleh Siregar (1994) bahwa hijauan dikategorikan pada kualitas rendah apabila kandungan protein kasarnya kurang dari $5 \%$, kualitas sedang apabila kandungan protein kasar adalah 5--10\%, dan kualitas tinggi apabila protein kasar hijauan adalah lebih besar dari 10\%. Wahyono dan Hardianto (2004) menyatakan bahwa kebutuhan protein kasar pada pakan sapi potong yaitu sebesar 10--12\%.

Keadaan padang penggembalaan yang terdapat di rawa Kecamatan Menggala belum memenuhi stdanar yang ditentukan, namun dalam kenyataan ternak kerbau yang terdapat pada rawa Kecamatan Menggala hanya memanfaatkan rumput yang ada sebagai makanannya dan tetap dapat berkembang biak dengan baik. Hal ini disebabkan karena bibit ternak kerbau rawa Kecamatan Menggala tersebut adalah kerbau lokal tanpa adanya perkawinan silang atau didatangkan dari luar sehingga kerbau-kerbau ini telah beradaptasi dengan kondisi alam setempat dan merupakan suatu keunikan tersendiri.

Kandungan rata-rata lemak kasar pada rumput rawa Kecamatan Menggala yaitu sebesar 4,51\%. Kandungan lemak kasar pada vegetasi di rawa Kecamatan menggala tingggi. Wahyono dan Hardianto (2004) menyatakan bahwa kebutuhan kadar lemak pada pakan sapi potong yaitu sebesar 2--3\%.

Kandungan abu pada rumput rawa Kecamatan Menggala yaitu sebesar 14,05\%. Wahyono dan Hardianto (2004) menyatakan bahwa kebutuhan kadar abu pada pakan sapi potong yaitu sebesar 6--9\%. Menurut Fathul (1999), abu ini merupakan komponen yang terdiri dari mineral. Abu ini berupa mineral yang terdapat dalam suatu bahan terdapat dalam suatu bahan dapat merupakan dua macam garam yaitu garam organik dan garam anorganik. Semakin tinggi kadar abu suatu bahan pangan, maka semakin buruk kualitas dari bahan pangan tersebut.

Kandungan BETN pada rumput rawa Kecamatan Menggala yaitu sebesar $42,16 \%$. Sari et al. (2015) menyatakan bahwa kandungan BETN rumput kumpai rata-rata yaitu sebesar 36,75--37,95\%. Kamal (1998) menyatakan bahwa BETN dipengaruhi oleh kandungan nutrien lainnya yaitu protein kasar, air, abu, lemak kasar dan serat kasar. Sutardi (2006) menyatakan bahwa kandungan BETN suatu bahan pakan sangat tergantung pada komponen lainnya, seperti air, abu, protein kasar, serat kasar dan lemak kasar. Penurunan kadar BETN dipandang dari aspek nutrien kurang menguntungkan, karena semakin sedikit BETN, berarti semakin sedikit pula komponen bahan organik yang dapat dicerna sehingga semakin sedikit pula energi yang dapat dihasilkan.

\section{SIMPULAN}

Komposisi botani di rawa Kecamatan Menggala, Kabupaten Tulang Bawang, Provinsi Lampung memiliki 5 spesies hijauan yaitu Hymenachne amplexicaulis, Cynodon dactylon L. Pars, Fimbristylis vahlii, Brachiaria plantaginea dan Isachne indica Nees 6,60\% dengan rata-rata nilai nutrien rumput rawa yaitu bahan kering 19,72\%; serat kasar 28,90\%; protein kasar 5,72\%; lemak kasar 4,51\%; abu 14,05\%; dan BETN 42,16\%. 


\section{DAFTAR PUSTAKA}

Anitawati, M. 1981. Nilai Gizi Daun Gliricidia (G. maculate HB dan G. sepium) sebagai bahan makanan kambing kacang. Thesis Fakultas Peternakan UGM. Yogyakarta.

Backer, C. A and R.C.B.V.D. Brenk. 1968. Flora of Java. Noordhaff N.V. Groningen. The Netherldans. Vol. 3.

Badan Pusat Statistik (BPS) Kabupaten Tulang Bawang. 2015. Kabupaten Tulang Bawang dalam Angka 2016. Tulang Bawang

2016. Kabupaten Tulang Bawang dalam Angka 2017. Tulang Bawang

Bambang. S, dan D. Priyanto. 2017. Degradasi Padang Penggembalaan. Balai Penelitian Ternak. Bab III-5 hal 97

Bethel, J. E., J. P. Liebeskind., and T. Opler 2005. Block share purchases dan corporate performance. J. Fin. 53(2): 605-634.

Bucio. R. D., R. G. Cook., and M. A.Cooke. 2005. An Auxin transport independent pathway is involved in phosphate stressinduced root architectural alternation in arabidopsi. J. Plant Phy. 71:421-425

Cope, D. M. S. Fayez., M. Mollaghasemi., and A. Kaylani. 2007. Supply Chain Simulation Modeling Made Easy: An Innovative Aproach.,Proceedings of the 2007 Winter Simulation Conference Vol. 1 page 7

Danuarsa. 2006. Analisis Proksimat dan Asam Lemak pada Beberapa Komoditas Kacang-kacangan. Buletin Teknik Pertanian 11 (1)

Fanindi. A., dan B. R. Prawiradiputra. 2017. Karakterisasi Dan Pemanfaatan Rumput Brachiaria Sp. Balai Penelitian Ternak. Bogor. Lokakarya Nasional Tanaman Pakan Ternak. Vol. 2 Hal. 156

Fariani, A dan Evitayani. 2008. Potensi Rumput Rawa sebagai Pakan Ruminansia: Produksi, Daya Tampung dan Kdanungan Fraksi Seratnya. Padang: Kampus Limau Manis. Universitas Sriwijaya. J. Indon. Trop. Anim. Agric. 33 (4) Dec. 2008

Fathul, F. 1999. Penentuan Kualitas dan Kuantitas Zat Makanan dalam Bahan Makanan Ternak. Jurusan Produksi Ternak. Fakultas Pertanian. Universitas Lampung. Lampung

Faturrahman. 1988. Analisis Vegetasi dan Produktivitas Rumput Rawa di Kecamatan Danau Panggang Kabupaten Hulu Sungai Utara, Kalimantan Selatan.
Karya Ilmiah. Fakultas Peternakan. Institut Pertanian Bogor. Bogor.

Gupta, A.K. and H. Thacker, 2013. Fimbristylis dichotoma. The IUCN Red List of Threatened Species 2013: e.T169008A68272468. http://dx.doi.org/10.2305/IUCN.UK.20 13-1.RLTS.T169008A68272468.en. diakses pada 08 November 2017.

Heyne, K. 1987. Tumbuhan Berguna Indonesia. Jilid I dan II. Terjemahan Badan Litbang Kehutanan. Cetakan I. Koperasi Karyawan Departemen Kehutanan Jakarta Pusat

Kamal, M. 1998. Bahan Pakan dan Ransum Ternak. Yogyakarta: Fakultas Peternakan. Universitas Gadjah Mada

Lansdown, R.V. 2013. Isachne globosa. The IUCN Red List of Threatened Species 2013: $\quad$ e.T168638A1193827. http://dx.doi.org/10.2305/IUCN.UK.201 3-1.RLTS.T168638A1193827.en. di akses pada 08 November 2017

Mathius, I. W., M. Rangkuti dan A. Djajanegara. 1981. Daya Konsumsi dan Daya Cerna Gliricidia (G. maculate HB dan K). Lembaran LPP

Rohaeni, E.S., A. Hamdan, R. Qomariah dan A. Subhan. 2007. Inventarisasi dan Karakterisasi Ternak Kerbau di Kalimantan Selatan. Laporan Hasil Penelitian. BPTP Kalimantan Selatan

Sari, M. L., A. I. M. Ali., S. Dani dan A. Yoldana. 2015. Kualitas Serat Kasar, Lemak Kasar, dan BETN terhadap Lama Penyimpanan Wafer Rumput Kumpai Minyak Dengan Perekat Keragian. Jurnal Peternakan Sriwijaya. ISSN 2303-1093. 4 (2): 35-40

Siregar, S. B. 1994. Ransum Ternak Ruminansia. Cetakan I. Swadaya, Jakarta.

Sutardi, T. 2006. Landasan Ilmu Nutrien Jilid 1. Departemen Ilmu Makanan Ternak. Fakultas Peternakan Institut Pertanian Bogor. Bogor

Wahyono. D. E. dan R. Hardianto. 2004. Pemanfaatan Sumber Daya Pakan Lokal untuk Pengembangan Usaha Sapi Potong. Grati. Pasuruan 